\title{
What is the right level of spending needed for health and care in the UK?
}

Anita Charlesworth, Michael Anderson, ${ }^{*}$ Cam Donaldson, Paul Johnson, Martin Knapp, Ali McGuire, Martin McKee, Elias Mossialos, Peter Smith, Andrew Street, Michael Woods

*With the exception of the Lead Author, the remaining co-authors are listed alphabetically as they provided equal contributions to this paper

\section{Abstract}

The health and care sector plays a valuable role in improving population health and societal wellbeing, protecting people from the financial consequences of illness, reducing health and income inequalities, and supporting economic growth. However, there is much debate regarding what is the appropriate level of funding in the UK. In this paper we look at the economic impact of the COVID-19 pandemic, historical spending in the UK and comparable countries, assess the role of private spending, and review spending projections to estimate future needs. Public spending on health has increased by $3 \cdot 7 \%$ a year, on average, since the NHS was founded in 1948 , and has assumed a larger share of both the economy and government expenditure. Over the last decade, except during the pandemic, the rate of growth of government spending for the health and care sector has slowed. We argue that without average growth in public spending on health of at least $4 \%$ per year, in realterms, there is a real risk of degradation of the NHS, reductions in coverage of benefits, increased inequalities and increased reliance on private financing. COVID-19 has highlighted major issues in the capacity and resilience of the health and care system. We recommend an independent review to examine what additional funds are required to better equip the UK to withstand further acute shocks and major threats to health. A similar, if not higher, level of growth in public spending on social care is needed in order to provide high standards of care and decent terms and conditions for 
social care staff, alongside an immediate uplift in public spending to implement long-overdue reforms recommended by the Dilnot Commission to improve financial protection.

\section{Introduction}

Since the National Health Service (NHS) was founded in 1948, public spending on health has more than doubled from 3.5 percent of Gross Domestic Product (GDP) to $7 \cdot 2$ percent in $2018-19 .{ }^{1,2}$ In real terms, spending is over ten times the amount it was seventy years ago. ${ }^{1}$ Despite the scale of the growth in health and care spending, there have been repeated 'crises' as funding increases have not kept pace with rising demand, expectations or technological needs. ${ }^{3}$

In recent years, measures to cope with the gap between demand and funding in the UK have involved measures such as raiding capital expenditure to boost revenue spending and restricting growth in staff pay alongside announcements to increase public funding such as the 2018 pledge to increase funding for the NHS in England by $f 20 \cdot 5$ billion in real terms per year by $2023-24,{ }^{4}$ and the 2019 pledge to increase capital investment in the NHS in England by $f 1 \cdot 8$ billion. ${ }^{5}$

We argue that instead of short-term and reactive funding measures, a longer-term solution for both NHS and social care funding is necessary for a sustainable health and care service, which we define as a service which provides as a minimum, similar levels of quality and access as currently enjoyed, taking into account future trends in demography, morbidity and technology. Increased investment is also needed to improve the preparedness and resilience of the health and care system to withstand further acute shocks and major threats to health. Survey data indicates that, if funding for the NHS were to increase, the majority of the public would support tax increases. ${ }^{6}$ Public views on who should pay for social care are more nuanced, but more than half believe the government should pay, although perhaps only for those on low incomes. ${ }^{7}$ 
However, there needs to be increased clarity about the level of funding necessary for a sustainable health and care service. This paper attempts to provide further clarity, while also being conscious of the significant economic uncertainty created by the COVID-19 pandemic. Consequently, we begin with a discussion of the state of the economy and potential economic impact of the recent COVID-19 pandemic. We then discuss the following policy questions, linked to the fiscal sustainability challenges identified by the Office for Budget Responsibility (OBR), ${ }^{8}$ and Organisation for Economic Cooperation and Development (OECD): ${ }^{9}$

1. What is the contribution of the health and care sector to wider society?

2. How does health spending in the UK compare to other countries?

3. How has health and care spending changed over time?

4. How does health and care spending vary across the UK?

5. What is the role of private spending on health in the UK?

6. What level of spending is needed for a sustainable health and care service?

Panel 1: Key Messages

- According to estimates by the OBR, OECD, and IFS, we can expect GDP to reduce between $9.5 \%$ and $14.3 \%$ in 2020, whilst future growth is highly uncertain and dependent upon the any further waves of COVID-19 infections and access to an effective vaccine.

- Achieving increased health spending against this economic backdrop requires a combination of increased government borrowing in the short-term and taxation in the medium to long-term.

- There is a strong economic rationale to invest in the health and care sector, to improve health, societal wellbeing, and reduce health and income inequalities. 
- In common with countries across the OECD, health spending in the UK has grown faster than the overall economy. However, growth in health and care spending has been highly volatile, with periods of relative plenty followed by periods of relative austerity.

- Spending volatility is not conducive to long-term planning and efficiency; to secure the long-term future of the NHS, there is a need for increased consensus regarding the right level of spending for health and care in the UK.

- While responsibility for health and care delivery is devolved, spending decisions in England impact Scotland, Wales and Northern Ireland through proportional allocations set by the Barnett formula.

- Private spending on health plays a limited role in the UK, and a major strength of the NHS is in providing protection against the financial consequences of ill-health.

- For the NHS, to meet cost and demand pressures over the next 15 years, spending needs to grow by at least 3.3\% per year, on average, in real terms. However, to improve the quality of services, reduce waiting times, increase staffing numbers and invest in capital, spending will need to grow by at least $4 \%$ year, on average, in real terms.

- For social care, to meet cost and demand pressures over the next 15 years spending needs to grow at 3.9\% per year, on average, in real terms. Improving financial protection by introducing a $£ 100,000$ means tested threshold and $£ 75,000$ maximum contribution in England, would require even more in social care spending.

- In the short-term, a further uplift in public spending is needed to address growing unmet need for healthcare services caused by postponing or cancelling elective procedures and diagnostic tests during the pandemic.

- We also recommend an independent review to examine what additional funds are required to improve the preparedness and resilience of the health and care system to withstand further acute shocks and major threats to health. 
The economy and the COVID-19 pandemic

The social distancing measures implemented in response to the pandemic were necessary to slow the spread of coronavirus and limit excess mortality, but they have also closed down business activity in many sectors and had a dramatic impact on the UK's economic output. Estimates although uncertain - by the OBR, ${ }^{10}$ OECD, ${ }^{11}$ and Institute for Fiscal Studies (IFS), ${ }^{12}$ expect GDP in the UK to reduce between $9.5 \%$ and $14.3 \%$ in 2020 . Future growth is highly dependent upon any further waves of infections and access to an effective vaccine, however these projections generally expect GDP to recover to pre pandemic levels by 2022. Future economic growth is also uncertain due to the UK leaving the European Union (EU). Most projections indicate that growth of the UK economy will be smaller leaving the EU than it would have been with continuing membership of the EU. ${ }^{13}$

Combined with the impact of a weaker economy, the OBR's central scenario expects government borrowing to reach just under $£ 400$ billion in $2020 .^{10}$ This would be the highest deficit since the Second World War. However, there is consensus among economists that immediate reductions in public spending or acute rises in taxation would make the long-term situation worse..$^{14,15}$ Increased public spending is needed to support individuals and businesses through, for example, furloughing, grants and loans, and to mitigate against potential long-term impacts on the economy from otherwise viable businesses failing, and high and sustained unemployment. Moreover, the period of austerity preceding the pandemic left the health and care system under-resourced and vulnerable to an acute shock and major threats to health. This ultimately exacerbated the economic impact of the pandemic itself, and has reinforced the economic case for developing a resilient health and care system. This will require the UK government to commit to sustained increases in health and care 
spending, as well as placing improving health and societal wellbeing at the heart of policy making. Whilst we acknowledge it will be challenging to achieve this in the current economic climate, we argue this could be achieved through a combination of increased government borrowing in the short-term and taxation in the medium to longer term.

\section{What is the contribution of the health and care sector to wider society?}

The health and care sector is valuable: it improves the health and wellbeing of the population, reduces inequalities and improves societal welfare. The sector also improves productivity and output through the associated increases in population health, which is especially important as the pension age is increasing. Furthermore, it is a large part of the economy, with 4.5 million jobs (approximately one in eight jobs in the UK, and nearly one in six jobs in Wales) in the health and social care sector in 2018. ${ }^{16}$

Health spending and health outcomes

The contribution that health spending makes toward improving health outcomes has been difficult to establish because outcomes are influenced by a range of environmental, social and economic factors beyond the health and care system. Moreover, analysis of historic trends is not necessarily a predictor of future trends. Nevertheless, there are some studies that attempt to quantify the link between health system spending and health outcomes. ${ }^{17}$ Research using the concept of amenable mortality, ${ }^{18}$ now incorporated in the Health Access and Quality Index, has shown that effective and timely healthcare makes a substantial contribution to population health. ${ }^{19}$ Several analyses of NHS programme budgeting data show a clear link between increased health spending and improved health outcomes in the NHS, with the cost of securing an extra quality-adjusted life year (QALY) ranging between $£ 5,000$ and $£ 15,000 .{ }^{20-22}$ At the macro level, an analysis of $\mathrm{OECD}$ countries concluded that increased health and care expenditure was associated with better health outcomes. ${ }^{23}$ The return on expenditure varies across countries, being lowest in the US, partly 
because high prices mean that expenditure 'buys' a lower volume of healthcare. ${ }^{24,25}$ Recent research by the OECD found that, across 35 member countries between 1995 and 2015, a 10\% increase in health spending was associated with a life expectancy gain of 3.5 months, ${ }^{26}$ although no measures of uncertainty were included in this analysis. Some of these macro-level analyses overlook how the impact of health spending on health outcomes is also dependent on how resources are allocated throughout the system. For example, investments in prevention may increase life expectancy more than investments in end-of-life care, or investments in front-line services may improve health outcomes more than investments in high-cost drugs or medical devices. Therefore, as health systems continue to manage resources in a climate of resource scarcity, optimising allocative efficiency will be an essential strategy to maximise the health gains from health spending.

\section{Health outcomes and economic growth}

There is growing literature focusing on the effect of improving health outcomes on macroeconomic growth and the mechanisms through which this occurs; although this is a challenging area to find causal evidence. Nevertheless, better health has been shown to increase labour market participation and worker productivity, which can increase economic growth. ${ }^{27}$ There is also evidence that increased life expectancy increases incentives to invest in education, ${ }^{28,29}$ which in turn can improve productivity. Poor health during childhood has also been shown to be a predictor of worsened health in later life..$^{30,31}$ Therefore, as improved health can increase overall labour force participation, especially near and post retirement age ${ }^{32,33}$ childhood health can have long-lasting effects on labour force participation and economic growth. Furthermore, illness and disability increase the likelihood of being unemployed in the UK, ${ }^{34}$ and being unwell at work (so-called presenteeism) is responsible for significant cost to the UK economy. ${ }^{35}$ The International Monetary Fund (IMF) has also found evidence that providing greater access to health services can reduce the decline in total factor productivity and thus economic growth from an ageing workforce. ${ }^{36}$ The COVID-19 pandemic has also demonstrated the extreme effect that a health crisis can have on the economy. 
Health spending, societal welfare and inequality

Beyond the potential benefits for macroeconomic growth, well directed health and care expenditure improves overall societal welfare. For example, improved health in old age can reduce isolation, and facilitate greater participation in society. The reverse is also true: care expenditure to reduce social isolation has health benefits. ${ }^{37,38}$ People also derive utility from the knowledge that other people can access healthcare: a so-called 'caring externality'. ${ }^{39} \mathrm{~A}$ key founding motivation for the NHS was that the sick deserve care, irrespective of their financial circumstances or contributions to the economy. ${ }^{40}$ While the NHS has been largely successful in providing care based on clinical need and not on ability to pay, there remain significant inequalities in health outcomes. There is estimated to be a $7 \cdot 4$ year difference in life expectancy and an 18.9 year difference in healthy life expectancy between the highest and lowest deprivation deciles (Supplementary Material Figure 1). While the UK has experienced significant increases in life expectancy, rates of increase have slowed markedly since 2010 and, at some ages, reversed, ${ }^{41}$ an issue discussed further within the LSE-Lancet Commission paper on changing health needs..$^{42}$ However, it is important to emphasise the restricted influence of the health and care sector on health and wellbeing inequalities, which are strongly driven by a range of social determinants. ${ }^{43,44}$ Nevertheless, it has been argued that the NHS often 'picks up the pieces' when other parts of the social safety net fail. ${ }^{45}$

The NHS is funded through general taxation, which is generally progressive. Resources are also distributed using a needs-based resource allocation formula, which reflects deprivation. ${ }^{46}$ Broadly, the rich subsidise the poor and the employed subsidise the unemployed; and due to the positive association between health and income, the more-healthy subsidise the less-healthy, ${ }^{47}$ further reducing inequality. ${ }^{48,49}$ The redistributive effect also depends on the utilisation of healthcare. Evidence from the NHS in England, ${ }^{50}$ estimates the lifetime hospital costs as substantially higher in more deprived populations, thereby increasing the redistributive effect. 


\section{How does health spending in the UK compare to other countries?}

As displayed in Figure 1, the UK spent $10 \cdot 3 \%$ of GDP on health (including both public and private spending) in 2019, similar to the average of the EU15 (9•4\% of GDP). The highest spending countries in the EU are Germany $(11 \cdot 7 \%)$, France $(11 \cdot 2 \%)$, and Sweden $(10 \cdot 9 \%)$. The UK spent less than the average of the G7 (11·5\%), which includes the US (17.0\%). In $2018,78 \%$ of health spending in the UK was from public funds - similar to the share in the EU15 (77\%), but slightly above that in the G7 (73\%). Public spending includes government spending or compulsory health insurance, whereas private spending includes any voluntary health insurance (VHI) or out of pocket payments. ${ }^{51}$ The OECD definition of health spending includes aspects of long-term care which conventionally are understood as social care spending in the UK context. ${ }^{51}$

Figure 1: Spending on health in G7 and EU15 countries (2019)

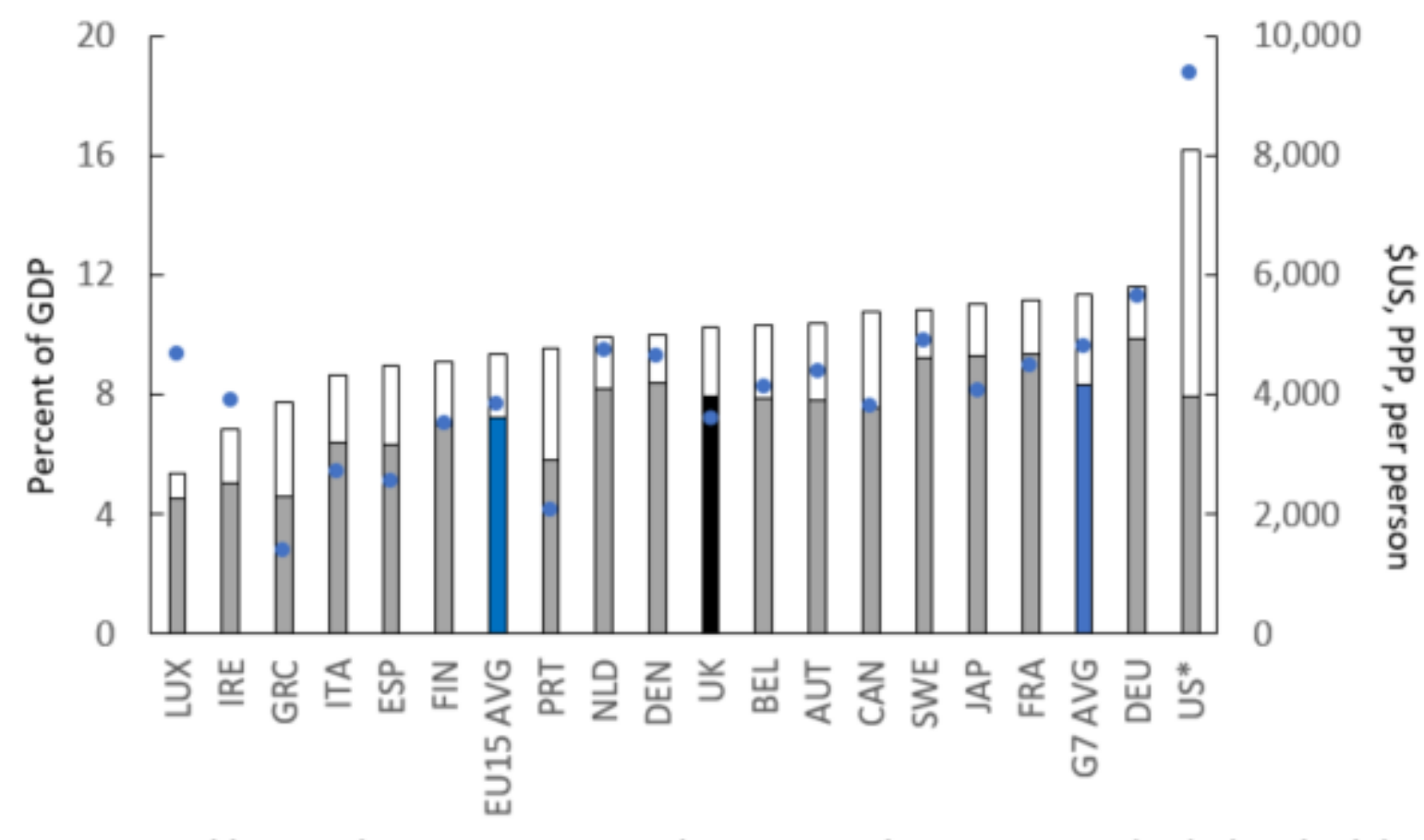

$\square$ Public spending $\square$ Private spending • Spending per person (Right hand side)

Source: $O E C D^{52}$ 
Note: *Public-private split data for the US reflects 2013. Whilst there is more recent data available older data is used to provide comparable split with data from other countries.

Whilst total spending on health as a proportion of GDP in the UK is above the EU15 average (10.3\% compared to $9.4 \%$ respectively), it is around 6\% lower than the EU15 average in \$US/person terms, $\$ 3,620$ compared to $\$ 3,837$ (Figure 1). With regards to the level of capital and workforce, the UK generally has less. For example, the UK has a relatively low number of hospital beds, diagnostics and clinical staff such as nurses and physicians (Supplementary Material Figure 2). Possible explanations for the low number of resources but similar spend could be differences in input prices such as physician wages, ${ }^{24}$ differences in skill-mix such as greater reliance on non-clinical staff, ${ }^{53}$ or an ongoing shift towards moving care delivery from hospitals to the community.

International comparisons of health spending, capital, and workforce should be interpreted with caution. Data may not be comparable and contextual factors contribute to variations. For example, low numbers of hospital beds could reflect either a lack of capital investment or successful efforts to move care away from the hospital to community settings. Similarly, low numbers of physicians and nurses may reflect an understaffed workforce, or different approaches to skill-mix across health and care workers. It should be noted that, while the UK has comparatively lower numbers of clinical staff such as nurses and physicians, the total health and care workforce is just above the average of EU15 and G7 countries (Supplementary Material Figure 3). 


\section{How has health and care spending changed over time?}

\section{Public spending on health}

Since the NHS was founded, spending has increased by more than inflation and GDP, rising by an average of $3 \cdot 7 \%$ a year in real terms. ${ }^{1}$ There are three major factors that determine the path of health spending over the long term: demographic factors, income effects and other cost pressures. ${ }^{54}$ Demographic factors include the age structure of the population, health status at given ages, and death-related costs. Income effects reflect that people generally demand more healthcare as their income rises. Other cost pressures include the impact of technological advancements and the increasing relative cost of healthcare. Over time these factors have led health spending in the UK to increase at a faster rate than national income. This is consistent with the pattern seen across OECD countries. $^{55}$

For almost every year throughout its existence, NHS spending has increased in real terms (Supplementary Material Figure 4). ${ }^{1}$ On only three occasions have there been notable spending reductions, twice in the early 1950s and in 1977-78 when the IMF was called upon to support the UK economy. However, year-on-year spending growth has been highly volatile with periods of relative plenty followed by periods of relative austerity. Between 1948 and 1978 spending increased on average by $3 \cdot 5 \%$ a year. During the Conservative Governments of 1979 to 1997 , spending growth was slightly lower at $3 \cdot 3 \%$ a year. Spending growth increased substantially under the Labour Governments between 1997 and 2009, averaging 6\% a year. ${ }^{56}$ Between 2010 and 2018, health spending has grown at a markedly lower rate of just $1 \cdot 2 \%$ a year. ${ }^{56}$ Figure 2 shows per capita and age-adjusted per capita health spending. The UK population has been increasing in size, so per capita spending has been increasing at a slower rate than NHS expenditure. Moreover, the composition of the population has been changing, and becoming older. This means that growth in age-adjusted 
spending is lower than growth in per capita spending, because older people tend to make greater use of healthcare. However, it is important not to overemphasise the contribution of population ageing, as individuals generally still see most health expenditure in their last year of life even as the population ages. It has been estimated that, independent of population ageing, cost growth and technological advancements will be the main drivers of future growth in health spending. ${ }^{57}$

Figure 2: Index of real UK health spending $(2009-10=100)$

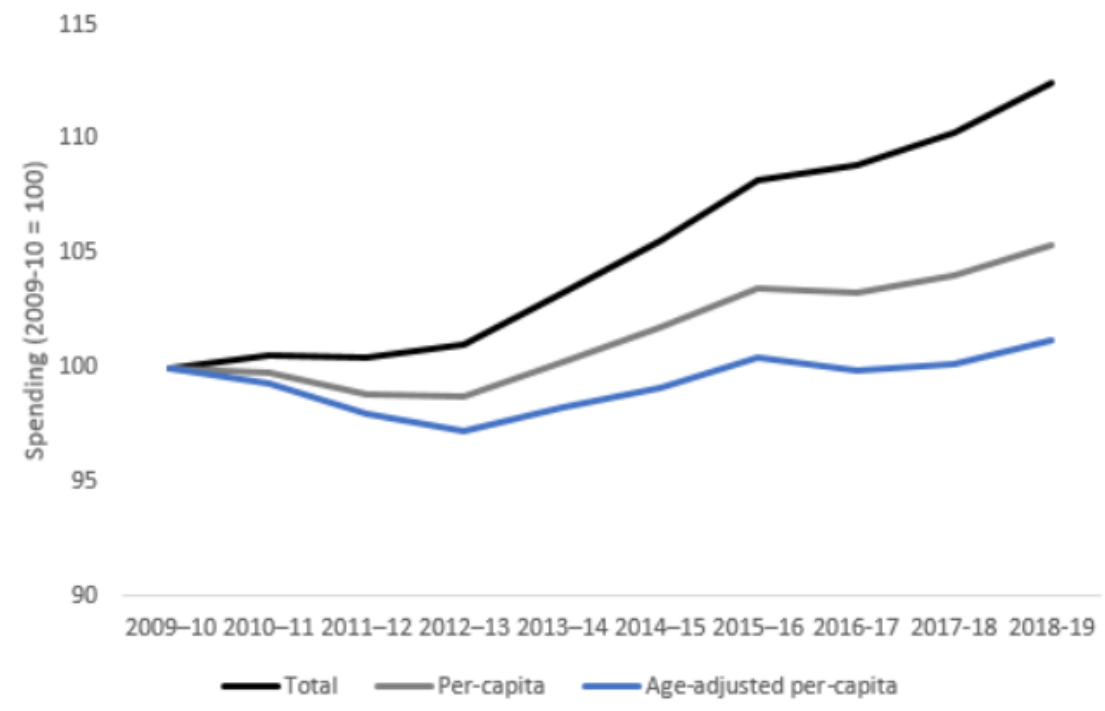

Source: Authors calculations using data from UK Government Public Expenditure Statistics Analyses, ${ }^{2} \mathrm{OBR}^{58} \mathrm{ONS}^{59}$

\section{Public spending on social care}

The health and care sectors are linked, and many ill people require support from both. If health and care services are complementary, reduced spending on social care may put greater pressure on the health sector, and vice versa. Figure 3 shows per capita and age-adjusted per capita adult social care spending. While spending on adult social care has reduced in real-terms over the last decade, the reduction is significantly larger when adjusted for per capita and age-adjusted per capita spending. 


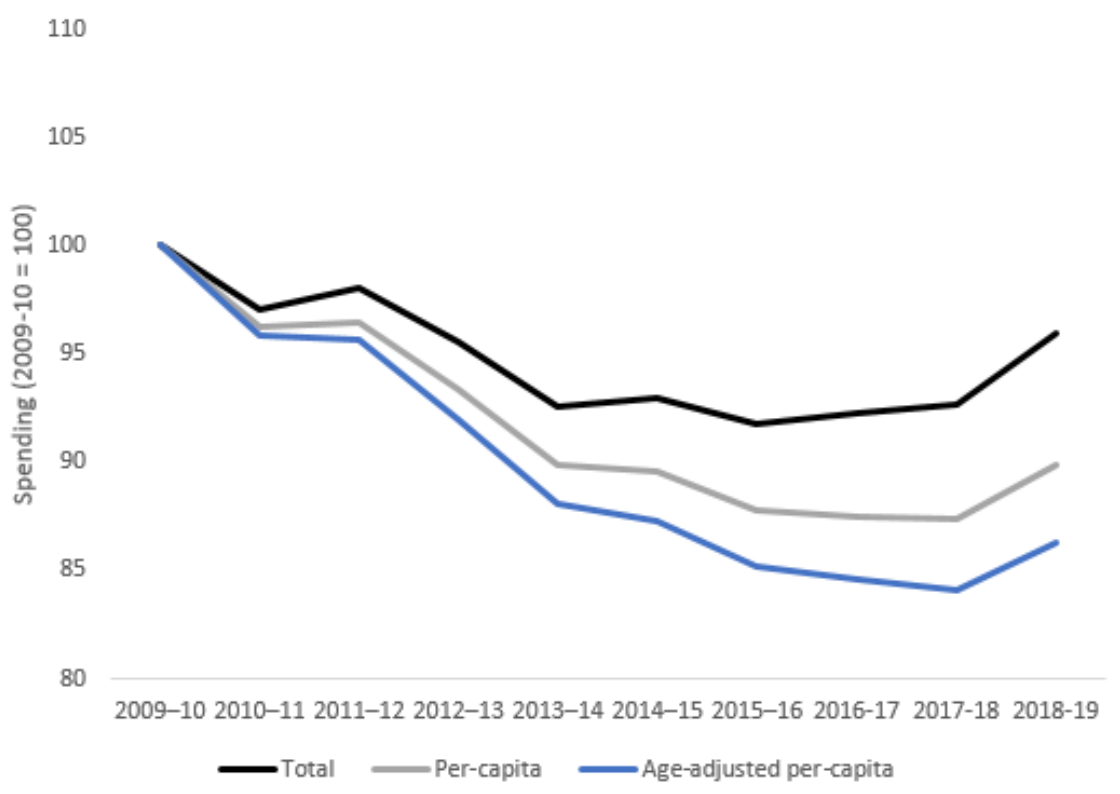

Source: Authors calculations using data from UK Government Public Expenditure Statistics Analyses, ${ }^{2} \mathrm{OBR}^{58} \mathrm{ONS}^{59}$

How does health and care spending vary across the UK?

Public spending on health across the UK

The funding system in each of the four countries of the UK remains tax-based and free at the point of use, with divergence in terms of the use of prescription charges (see role of private spending below). Publicly funded health spending per head of population varies across the four UK countries (Supplementary Material Table 1). Total funding allocations to each UK country for government spending are based on a combination of historical spending and the Barnett formula which proportionally adjusts any uplift in government spending in England according to population size to Scotland, Wales and Northern Ireland.$^{60}$ Each UK nation then decides how to allocate their resources during annual spending reviews. Within England, around two-thirds of the NHS budget is allocated via weighted capitation payments to local commissioning bodies taking account of population 
factors such as age, gender and deprivation. ${ }^{46}$ Outturn spending per person is highest in Scotland and lowest in England (Supplementary Material Table 1).Although there are regions in England such as the North East and London with higher spending per person than Scotland. Differences across the UK in spending per person have narrowed, ranging from $£ 1,598-£ 2,471$ in $2010-11$, to $£ 1,915-£ 2,665$ in 2017-18 (Supplementary Material Table 1). This trend warrants further investigation, as it is not clear if demographic changes in relative need between regions are responsible, or if other contributory factors exist.

Once allocated to local commissioning bodies in England, an internal market exists whereby both NHS and independent sector hospitals are eligible to provide treatment for NHS patients. In 2017-18, independent sector hospitals provided over 600,000 publicly funded elective procedures, $6 \%$ of all NHS elective activity, growing from less than 2000 elective procedures in 2003-4. ${ }^{61}$ For some procedures such as hip replacements, independent sector hospitals now provide $30 \%$ of all NHSfunded procedures.$^{61}$ Analysis indicates that such reforms, despite less-complex patients being treated in the independent care sector, may have improved access and outcomes. ${ }^{62,63}$ However, concerns have been raised regarding a relative lack of transparency in independent sector hospitals, ${ }^{64}$ and the potential impact on the sustainability of NHS services. ${ }^{65}$ During the pandemic, independent sector hospitals have been used to allow the continuation of NHS cancer treatment and elective procedures in facilities less exposed to COVID-19. ${ }^{66}$

\section{Public spending on social care across the UK}

The constituent countries of the UK are responsible for social care within their jurisdictions. This has led to variation in eligibility criteria, and differences in patterns of both funding and delivery. For example, in Scotland, personal and nursing care are free, whereas in England all social care is meanstested (Supplementary Material Table 2). The latter can lead to substantial costs incurred by older people needing social care support. The Dilnot Commission (2011) on social care in England found that one in ten people, at age 65 , would face future lifetime care costs of $f 100,000 .{ }^{67}$ 
Social care spending per adult is 31\% lower in England than in Scotland, where there is a system of free personal care for older people (Supplementary Material Table 3). While differences between the four UK nations may reflect differences in eligibility criteria and needs, they also reflect larger cuts to social care in England since 2011 (Supplementary Material Table 3). This system has led to unequal funding of social care services across the UK. The IFS estimated that between 2009-10 to $2017-18$, councils amongst the most deprived areas made cuts to adult social of care of $17 \%$ per person as compared to cuts of $3 \%$ per person in councils among the least deprived areas. ${ }^{68}$ These differences in social care eligibility and funding across the UK do not appear to have influenced preparedness against COVID-19, as all constituent countries experienced significantly increased excess mortality in care homes during the pandemic. ${ }^{69-71}$

\section{What is the role of private spending on health in the UK?}

There is no developed country where private spending is the predominant financing mechanism for healthcare services (Figure 1). Even in countries such as the US, which has a more extensively privatised financing model, there is still a significant public system to provide coverage for lowincome, elderly and veteran populations. Indeed, despite significant private financing, public spending in the US still accounts for a higher percentage of GDP than in the UK (Figure 1). Notably also, countries with more privatised models have higher inequalities in access to healthcare services, ${ }^{72}$ a lower redistributive effect between income groups, ${ }^{47}$ and a higher incidence of catastrophic health expenditure. ${ }^{73}$

In the UK, private spending on health is just over a fifth of all spending. ${ }^{56}$ However, the majority of the private spending on health is concentrated among individuals in the highest income quintile, ${ }^{74}$ with those in the lowest income quintile typically exempt from out-of-pocket payments to access NHS services. ${ }^{75,76}$ Generally, compared to other high-income countries, a major strength of the NHS 
is financial protection, evidenced by a comparatively low incidence of catastrophic health expenditure, which is defined as out-of-pocket payments for healthcare services exceeding a certain proportion of household income (Supplementary Material Figure 5). Factors which influence the level of financial protection in any country include gaps in coverage, the frequency and size of outof-pocket payments, and whether coverage policy is designed in a manner which minimizes out-ofpocket payments for poor people and regular users of healthcare services. ${ }^{77}$

Household health expenditure accounts for just under $70 \%$ of private spending in the UK and includes both direct purchases of medical goods and services by households, and consumption of treatment funded through VHI. ${ }^{78}$ Overall, payments for pharmaceuticals (co-payments and over-thecounter) make up around a third (34\%) of household health expenditure, followed by therapeutic appliances and equipment (20\%), hospital services (18\%), dental services (12\%) and outpatient medical services (10\%). ${ }^{78}$ Prescription charges apply only in England (although approximately $90 \%$ of prescriptions are exempt from charges), having been abolished in Wales (2007), Northern Ireland (2010) and Scotland (2011). ${ }^{79}$ Income inequality in unmet need is greater for dental care than medical care, with those in the poorest quintile consistently more likely to report unmet need for dental care due to cost, distance or waiting times. ${ }^{80}$

In addition to out-of-pocket expenditure, there is VHI for both dental and general health plans. In $2016,10 \cdot 5 \%$ of the UK population had some form of $\mathrm{VHI}, 8 \%$ through employer paid schemes, and $2.5 \%$ through individually paid schemes. ${ }^{81}$ The numbers insured fell slightly following the recession in 2008 but have now stabilised, although there has been a gradual decrease in the number of individually paid subscribers. ${ }^{81}$ The share of households with VHI varies significantly by income quintile, with over $20 \%$ of those in the richest quintile and less than $5 \%$ of those in the poorest quintile having VHI. ${ }^{80}$ There is also significant variation regionally, with nearly half of the share of UK spending on VHI concentrated in London and the South East (Supplementary Material Table 4).

\section{What level of spending is needed in the future for a sustainable health and care service?}




\section{Projections of health spending}

Projections of health spending are essential to understand the level of spending needed in the future for a sustainable health and care service. These need to take account of the goals of the health system, such as maintaining quality and access to a range of services, in line with public expectations. A number of bodies such as the OBR and the OECD produce top-down projections of health spending for the UK and other countries (Table 1). This involves focusing on the three main drivers of health spending categorised as: demographic factors; income effects; and other cost pressures. ${ }^{82}$ The IFS and Health Foundation (HF), and the Institute for Public Policy Research (IPPR) have produced bottom-up projections of health, which are populated with component-based data, such as drug costs, provider activity and salaries (Table 1 ). These projections were all made prior to the COVID-19 pandemic, and thus do not factor the consequences of the pandemic or additional funding required for preparedness to withstand further acute shocks and major threats to health. Arguably the bottom-up projections better capture factors relevant to the UK, and consequently provide more robust forecasts. This approach does, however, require significantly more countryspecific data than the top down approach, making it less feasible if projecting expenditure for many different countries. However, synergies can be identified between the top-down and bottom-up approaches. Both approaches take account of long-term projections of GDP growth, produced by organisations such as the $\mathrm{OBR},{ }^{83}$ and $\mathrm{OECD} .{ }^{84}$

Table 1: Selected Projections of public spending on health in the UK

\begin{tabular}{|c|c|c|c|}
\hline & $\begin{array}{c}\text { Baseline } \\
\text { expenditure } \\
\% \text { GDP (year in } \\
\text { brackets) }\end{array}$ & $\begin{array}{c}\text { Annual, real } \\
\text { growth }\end{array}$ & $\begin{array}{l}\text { Projected expenditure } \\
\qquad \% \text { GDP }\end{array}$ \\
\hline \multicolumn{4}{|c|}{ Top-down Projections } \\
\hline OECD (cost-containment) & $6 \cdot 5 \%(2010)$ & $\mathrm{n} / \mathrm{c}$ & $7 \cdot 9 \%(2030)$ \\
\hline
\end{tabular}




\begin{tabular}{|c|c|c|c|}
\hline & & & (1.4\% increase) \\
\hline OECD (constant cost-pressure) & $6 \cdot 5 \%(2010)$ & $\mathrm{n} / \mathrm{c}$ & $\begin{array}{c}8 \cdot 4 \%(2030) \\
\text { (1.9\% increase) }\end{array}$ \\
\hline OBR & $\begin{array}{c}7 \cdot 1 \% \\
(2017-18)\end{array}$ & $\mathrm{n} / \mathrm{c}$ & $\begin{array}{l}9 \cdot 9 \%(2037-38) \\
(2 \cdot 8 \% \text { increase })\end{array}$ \\
\hline \multicolumn{4}{|c|}{ Bottom-up Projections } \\
\hline HF/IFS (Status quo) & $7 \cdot 3 \%(2018-19)$ & $\begin{array}{c}3 \cdot 3 \%(2033- \\
34)\end{array}$ & $\begin{array}{l}8 \cdot 9 \%(2033-34) \\
(1 \cdot 6 \% \text { increase })\end{array}$ \\
\hline HF/IFS (Modernised scenario) & $7 \cdot 3 \%(2018-19)$ & $\begin{array}{c}4 \cdot 0 \%(2033- \\
34)\end{array}$ & $\begin{array}{l}9 \cdot 9 \%(2033-34) \\
(2 \cdot 6 \% \text { increase })\end{array}$ \\
\hline IPPR (England) & $\mathrm{n} / \mathrm{c}(2016-17)$ & $\begin{array}{c}3 \cdot 8 \%(2029- \\
30)\end{array}$ & $\mathrm{n} / \mathrm{c}$ \\
\hline
\end{tabular}

Source: Authors own analysis using data from $\mathrm{OBR},{ }^{58} \mathrm{OECD},{ }^{55} \mathrm{IPPR},{ }^{85}$ and $\mathrm{HF} / \mathrm{IFS}^{1} . \mathrm{n} / \mathrm{c}$ : not calculated

Alongside demographic and income effects, top-down projections such as those from the OECD and OBR are impacted upon particularly by alternative cost-pressure scenarios, which take account of assumptions related to input prices (i.e. labour, goods and services and fixed capital), technological advances and changes in policy. The OBR and OECD projections assume that healthcare sector productivity is lower relative to the rest of the economy. This is partially due to the Baumol effect, a theory which suggests that in labour-intensive industries, such as the healthcare sector, wages must keep pace with those in sectors with higher productivity potential. The significance of the Baumol effect is debated, ${ }^{87}$ although both the OECD and the OBR assume there is a Baumol effect for healthcare, with pay increasing faster than productivity growth. The Baumol effect is often cited as contributing to rising health spending although Baumol himself reflected that such increased spending on health is neither necessarily unsustainable nor problematic as long as that spending is seen to be valued by society. ${ }^{88}$ The relationship between technological advances and health spending is also complex and often conflicting..$^{89}$ In different cases, technology can increase costs, be 
cost-neutral or even cost-saving. However, even if a technology is cost-saving overall health expenditure may increase as the new technology allows expansion of treatment, increasing treatment volume and therefore increases overall expenditure. Therefore, there is considerable uncertainty regarding to what degree technology will increase costs in the future.

The effect of cost pressures is challenging to forecast and, not surprisingly, results in large variability in projections..$^{54}$ The OECD produces a cost-containment scenario which assumes that changes in policy act more strongly than in the past to rein in some of the expenditure growth, and an alternative scenario (the cost-pressure scenario) which assumes that cost pressures continue at $1 \cdot 7 \%$ a year, the average historical growth across all countries in the OECD. The cost-containment scenario projects spending for the UK to increase by $1 \cdot 4 \%$ of GDP, whilst the cost-pressure scenario projects an increase of $1 \cdot 9 \%$ of GDP by 2030. The OBR's projection draws upon a 2015-16 NHS England estimate of non-demographic cost pressures of $2.7 \%$ and $1.2 \%$ per year for primary and secondary care respectively. ${ }^{58}$ They assume these pressures will decline over time to $1 \%$ per year from 2036-37 onwards. The rationale for this assumption is that this decline might be expected as health spending takes up an even larger share of national income. This approach projects $2.6 \%$ of GDP increase in health spending by $2037-38$.

The HF/IFS bottom-up projections use two alternative scenarios. The status quo scenario takes account of core demand and cost pressures but does not provide sufficient funding to return waiting times to their target levels, support improvements to quality and outcomes or modernise the physical infrastructure of the health service. This scenario projects an annual real growth rate of $3 \cdot 3 \%$ for the UK, and public spending of $8 \cdot 9 \%$ of GDP by $2033-34$. The HF/IFS alternative scenario returns the NHS to prior levels of care quality and allows improvement in key priority areas of unmet need, including A\&E performance, waiting times for elective care and outpatient appointments, mental health, capital spending and public health. This scenario projects an annual average real growth rate of $4 \%$ and public spending of $9 \cdot 9 \%$ of GDP by $2033-34 .{ }^{1}$ Further areas of unmet need are 
identified in other accompanying LSE-Lancet Commission background papers such as the health and care workforce, ${ }^{53}$ and health information technology. ${ }^{90}$ The $4 \%$ growth rate is also broadly consistent with the other bottom-up projections from the Institute for Public Policy Research which also uses a bottom-up methodology and projects a real annual growth rate of around a $3 \cdot 8 \% .{ }^{85}$

When analysing these approaches together, some conclusions can be made. Top-down projections demonstrate that assumptions related to input prices, technological advances and changes in policy significantly impact future estimates of health spending. From bottom-up projections, there is broad consensus that health spending needs to increase by $3 \cdot 3 \%$ to $4 \%$ in real-terms, per year. However, if we are to seek improvements in the quality of NHS care, rather than oversee its degradation, increases need to average at least $4 \%$ in real-terms, per year. Further evidence to support such increases in health spending is contained in our background paper on the health and care workforce, ${ }^{53}$ which estimates that increases in health spending of $4 \%$ in real-terms, per year, is necessary to sustain growth in the workforce at $2.3 \%$ per year. However, it is important to note these top-down projections were undertaken prior to the COVID-19 pandemic, and assume that GDP growth will increase, on average, by $1.9 \%$ per year until $2033-34 .{ }^{1}$ Therefore, these projections give an indication of the level of spending required for a long-term funding settlement for the NHS, assuming GDP growth in the long term returns to pre-pandemic projections. In the short-term, further increases in public spending will continue to be needed for the NHS to respond to the pandemic, and address the growing unmet need for healthcare services caused by postponing or cancelling elective procedures and diagnostic tests. We also recommend an independent review to examine what additional funds are required to improve the preparedness and resilience of the health and care system to withstand further acute shocks and major threats to health.

\section{Projections of Social Care Spending}

With current eligibility criteria maintained, HF/IFS adapted projections from the Personal Social Services Research Unit (PSSRU; now Care Policy and Evaluation Centre, LSE) to estimate that public 
funding for social care needs to increase by $3.9 \%$ per year until at least 2033 to meet demand

(Figure 4). These projections estimate future demand for adult social care by including projections of population size, age, gender, and prevalence of disability, and future expenditure by projecting the rising cost of providing social care services. Included in the expenditure projections is the assumption that health and social care costs rise in real terms in line with productivity, with an uplift to take account of the planned rises in the national living wage. ${ }^{91}$

\section{Figure 4: UK Social Care Spending Projections}

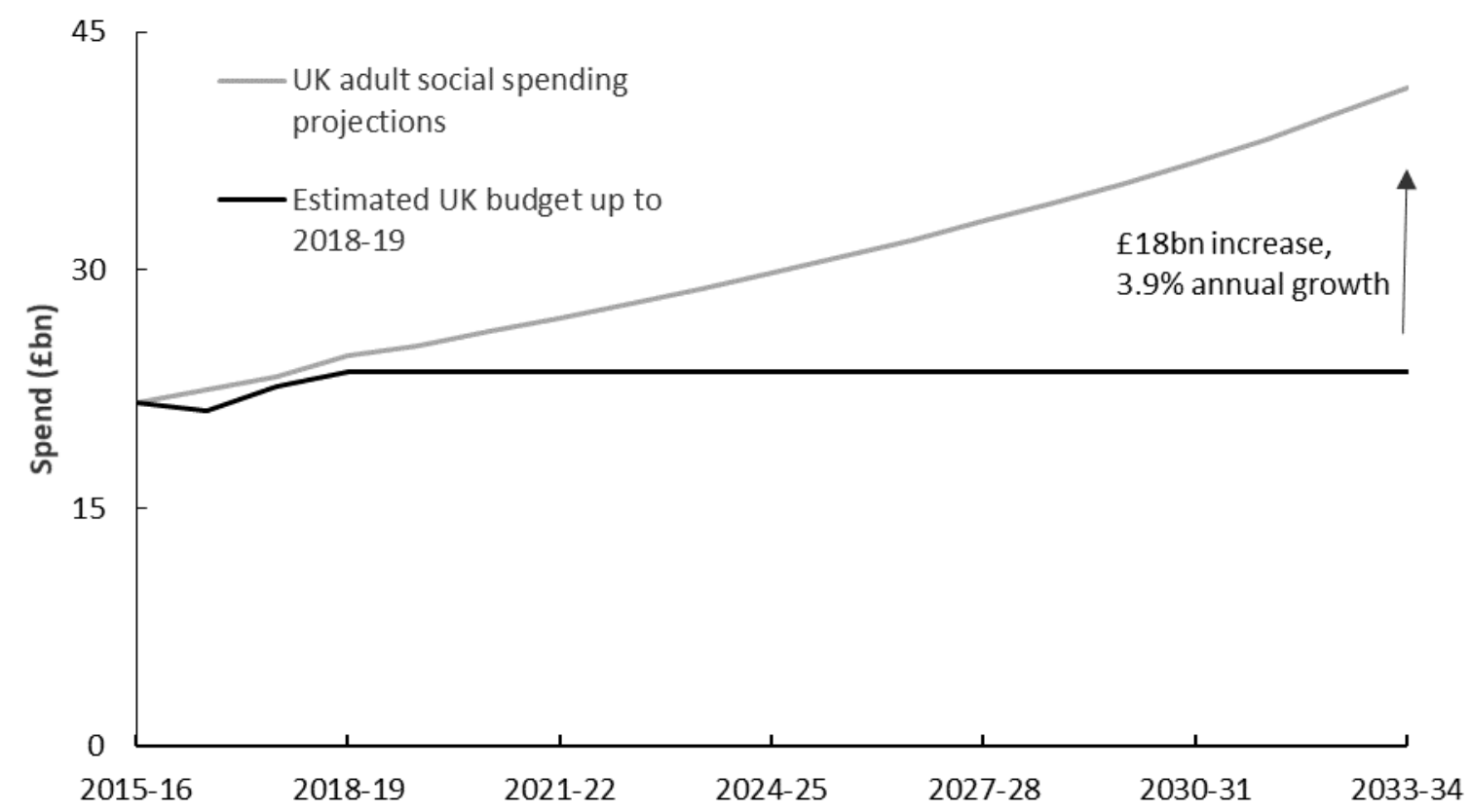

Source: $\mathrm{HF} / \mathrm{IFS}^{1}$ and PSSRU ${ }^{1,91}$

It is also important to note that reform of the social care model is long overdue. In England and Northern Ireland, current eligibility criteria and thresholds have remained unchanged since 2010-11. This has contributed to over 400,000 fewer people accessing publicly funded social care in England in 2016-17 than in 2009-10 despite growing needs associated with, for example, population ageing. ${ }^{92}$ Future public social care spending will be dependent upon whether and how social care funding is reformed. Different options have been explored to reach a long-term funding settlement for social care. The Dilnot commission on 'Fairer Care Funding' suggested a lifetime cap of individual 
contributions of $£ 35,000$, and a means-tested threshold of $£ 100,000 .{ }^{67}$ The government responded by initially suggesting introduction of a lifetime cap for individual contributions of $£ 75,000$, although this has been postponed indefinitely. ${ }^{93}$ The 2017 Conservative Manifesto proposed implementing a means-tested threshold of $£ 100,000$ as suggested by the Dilnot Commission. ${ }^{94}$ The 2019 Conservative Manifesto recommitted to the concept of improved financial protection, ${ }^{95}$ but no reform has taken place to date. No matter what reform is introduced for social care, a guiding principle should be to increase financial protection, so a substantial increase in public funding is likely to be required. For example, it has been estimated that to implement a $£ 100,000$ meanstested threshold and $£ 75,000$ life cap on individual contributions in England alone, would cost an additional $£ 3 \cdot 2$ billion (2018-19 prices). ${ }^{96}$

\section{Productivity and health spending}

Any claims made for increased spending on health or social care will need to come with the assurance that these funds will be put to good use. This is most commonly established by measuring productivity, which compares the amount of output produced against the inputs used by any particular sector of the economy. In the healthcare sector, outputs are measured by taking account of factors such as: the number of hospital patients treated as elective cases; day cases or emergency admission; and also the number of outpatient contacts in primary care, mental health and community trusts. ${ }^{97}$ These outputs are cost-weighted and adjusted according to quality using indicators such as: patient reported outcome measures; waiting times; survival in hospital settings; and the quality and outcomes framework (QOF) in primary care. ${ }^{97}$ Health outcomes such as life expectancy are not considered as outputs as these are not wholly attributable to the healthcare sector, also being impacted upon by sectors outside of health. Healthcare inputs include the number of doctors, nurses and support staff providing care, the equipment and clinical supplies used, and the hospitals and other premises where care is provided. ${ }^{97}$ If growth in output exceeds growth in 
input, healthcare productivity has increased. However, note productivity may increase if inputs have been cut.

The rate of productivity growth in the healthcare sector since the early 2000 s compares favourably with that achieved by other public sectors and the economy as a whole. ${ }^{98}$ However, the NHS, like the economy as whole, faces challenges in continuing to make productivity gains. ${ }^{99}$ There are concerns that positive past productivity growth will not persist into the future. Productivity gains may have been achieved by restricting growth in staffing levels, implying that existing staff have been working harder at a time when wage growth up to $2018 / 19$ was limited to $1 \%$ per annum. Such a position is not sustainable. To retain staff and keep them motivated, especially in a situation of reduced immigration, wages will have to increase in line with economy-wide average earnings. For social care, reductions in productivity may be due to high turnover of low paid staff employed in a sector characterised by weak employment conditions, which itself reflects an increasing mismatch between funding and current demand. Low wages and reduced bed availability have impacted morale and left providers not capable of improving productivity.

Staff also need the right equipment and technology to do their jobs. It has long been recognised that many of the more productive companies are those that have invested more heavily in capital and technology, ${ }^{100}$ a process termed 'capital deepening'. ${ }^{101}$ But in recent years the NHS has experienced the reverse. Capital funds have been raided to fund hospital deficits, leading to a backlog in maintenance and poor investment in technology. ${ }^{102}$ Capital Investment per NHS worker has fallen in real terms by $17 \%$ between $2010-11$ and $2017-18 .{ }^{103}$ This will need to be rectified in order to secure future productivity growth. Looking forward, working existing inputs harder will not be enough. It will be essential that the NHS becomes better at reducing inefficiency and unwarranted variations in practice.

\section{Conclusion}


This paper has covered a series of policy questions and a number of conclusions can be drawn. The health and care sectors undeniably play a valuable role in improving population health and societal wellbeing, reducing health and income inequalities, and supporting economic growth. The UK has witnessed a large increase in health spending since the NHS was established, but growth in spending has slowed significantly in recent years. The UK spends around the average of the EU15, but still less than many other comparable high-income nations. Funding for social care, in real terms, has decreased in recent years, which has implications for the NHS, as the two sectors are inextricably linked. Within the UK, there is variation in health and care spending, with Scotland, Wales and Northern Ireland all spending more per capita than England. The role of private spending also varies significantly, concentrated in high-income groups, particularly in London and the South East. We conclude that, for a sustainable health and care service, public spending on the NHS and social care will need to increase, on average, by at least $4 \%$ per year in real terms. An independent review is needed to estimate the additional funds required to improve the preparedness and resilience of the health and care system to withstand further acute shocks and major threats to health. The pandemic will be responsible for a significant recession that creates challenges to sustaining increases in health and care spending. It must be remembered that the NHS was established, shortly after World War II, during one of the most economically challenging times the UK has endured. The foundations for today's social care system were also laid at that time. As then, the NHS and social care will be integral to the recovery of the economy and society in general.

\section{References}

1 Charlesworth A, Johnson P. Securing the future: funding health and social care to the 2030s. The Health Foundation. Institute for Fiscal Studies. 2018 https://www.ifs.org.uk/publications/12994 (accessed Nov 26, 2020). 
2 HM Treasury. Public Expenditure Statistical Analyses 2019. 2019. https://www.gov.uk/government/statistics/public-expenditure-statistical-analyses-2019 (accessed Nov 26, 2020).

3 Mossialos E, McGuire A, Anderson M, Pitchforth E, James A, Horton R. The future of the NHS: no longer the envy of the world? The Lancet 2018; 391: 1001-3.

4 UK Government. Prime Minister sets out 5-year NHS funding plan. 2018 https://www.gov.uk/government/news/prime-minister-sets-out-5-year-nhs-funding-plan (accessed Nov 26, 2020).

5 UK Government. PM announces extra $£ 1.8$ billion for NHS frontline services. 2019. https://www.gov.uk/government/news/pm-announces-extra-18-billion-for-nhs-frontlineservices (accessed Nov 26, 2020).

6 The Kings Fund. Does the public see tax rises as the answer to NHS funding pressures? 2018. https://www.kingsfund.org.uk/publications/does-public-see-tax-rises-answer-nhsfunding-pressures (accessed Nov 26, 2020).

7 Wood C, Vibert S. A Good Retirement: Public attitudes to the role of the state and the individual in achieving financial security in later life. Demos, 2017 https://www.demos.co.uk/wp-content/uploads/2017/12/A-Good-Retirement.pdf (accessed Nov 26, 2020).

8 OBR. Fiscal risks report. 2019. https://obr.uk/docs/dlm_uploads/Fiscalrisksreport2019.pdf (accessed Nov 26, 2020).

9 OECD. Fiscal Sustainability of Health Systems. 2015

https://www.oecd.org/publications/fiscal-sustainability-of-health-systems9789264233386-en.htm (accessed Nov 26, 2020).

10 OBR. Economic and fiscal outlook: November 2020. 2020. http://cdn.obr.uk/CCS1020397650-001 OBR-November2020-EFO-v2-Webaccessible.pdf (accessed Nov 26, 2020).

11 OECD. OECD Economic Outlook, Volume 2020 Issue 1: Preliminary version. 2020. https://www.oecd-ilibrary.org/economics/oecd-economic-outlook/volume-2020/issue1_0d1d1e2e-en (accessed Nov 26, 2020).

12 Emerson C, Nabarro B, Stockton I. The outlook for the public finances under the long shadow of COVID-19. Institue of Fiscal Studies. 2020. https://www.ifs.org.uk/uploads/BN295-The-outlook-for-the-public-finances-under-thelong-shadow-of-COVID-19-2.pdf (accessed Nov 26, 2020).

13 Tetlow G, Stojanovic A. Understanding the economic impact of Brexit. Institue for Government. 2018.

https://www.instituteforgovernment.org.uk/sites/default/files/publications/2018\%20IfG\%2 0\%20Brexit $\% 20$ impact $\% 20 \% 5$ Bfinal $\% 20$ for\%20web\%5D.pdf (accessed Nov 26, 2020).

14 OECD. Tax and Fiscal Policy in Response to the Coronavirus Crisis: Strengthening Confidence and Resilience. 2020. https://www.oecd.org/ctp/tax-policy/tax-and-fiscal- 
policy-in-response-to-the-coronavirus-crisis-strengthening-confidence-and-resilience.htm (accessed Nov 26, 2020).

15 IMF. Fiscal Monitor: Policies for the Recovery. 2020. https://www.imf.org/en/Publications/FM (accessed Nov 26, 2020).

16 ONS. JOBS05: Workforce jobs by region and industry.

2019. https://www.ons.gov.uk/employmentandlabourmarket/peopleinwork/employmenta ndemployeetypes/datasets/workforcejobsbyregionandindustryjobs05 (accessed Nov 26, 2020).

17 Figueras J, Mckee M. Health systems, health, wealth and societal well-being: assessing the case for investing in health systems. European Observatory on Health Systems and Policies. Open University Press. 2012

18 Nolte E, McKee M. Variations in amenable mortality--trends in 16 high-income nations. Health Policy 2011; 103: 47-52.

19Fullman N, Yearwood J, Abay SM, et al. Measuring performance on the Healthcare Access and Quality Index for 195 countries and territories and selected subnational locations: a systematic analysis from the Global Burden of Disease Study 2016. The Lancet 2018; 391: 2236-71.

20 Martin S, Rice N, Smith PC. Does health care spending improve health outcomes? Evidence from English programme budgeting data. Journal of Health Economics 2008; 27: $826-42$.

21 Claxton K, Martin S, Soares M, et al. Methods for the estimation of the National Institute for Health and Care Excellence cost-effectiveness threshold. Health Technology Assessment 2015; 19: 1-504.

22 Lomas J, Martin S, Claxton K. Estimating the Marginal Productivity of the English National Health Service From 2003 to 2012. Value in Health 2019 22(9): 995-1002

23 Bradley EH, Elkins BR, Herrin J, Elbel B. Health and social services expenditures: associations with health outcomes. BMJ Qual Saf 2011; 20: 826.

24 Papanicolas I, Woskie LR, Jha AK. Health care spending in the united states and other high-income countries. JAMA 2018; 319: 1024-39.

25 Baicker K, Chandra A. Challenges in understanding differences in health care spending between the united states and other high-income countries. JAMA 2018; 319: 986-7.

26 James C, Devaux M, Sassi F. Inclusive growth and health. OECD Health Working Papers No 103. OECD. 2017. https://www.oecd-ilibrary.org/content/paper/93d52bcd-en (accessed Nov 26, 2020).

27 Bloom DE, Canning D, Kotschy R, Prettner K, Schünemann JJ. Health and Economic Growth: Reconciling the Micro and Macro Evidence. National Bureau of Economic Research Working Paper Series 2019. https://www.nber.org/papers/w26003.pdf (accessed Nov 26, 2020). 
28 Bloom DE, Canning D, Sevilla J. The Demographic Dividend: A New Perspective on the Economic Consequences of Population Change. RAND. 2003.

29 Cervellati M, Sunde U. Life Expectancy, Schooling, and Lifetime Labor Supply: Theory and Evidence Revisited. Econometrica 2013; 81: 2055-86.

30 Palloni A, Milesi C, White RG, Turner A. Early childhood health, reproduction of economic inequalities and the persistence of health and mortality differentials. Social Science \& Medicine 2009; 68: 1574-82.

31 Case A, Fertig A, Paxson C. The lasting impact of childhood health and circumstance. Journal of Health Economics 2005; 24: 365-89.

32 Blundell RW, Britton J, Costa Dias M, French E. The Impact of Health on Labor Supply Near Retirement. Institue for Fiscal Studies. 2017. https://www.ifs.org.uk/uploads/publications/wps/WP201718.pdf (accessed 26 Nov, 2020)

33 Kanabar R. Post-retirement labour supply in England. The Journal of the Economics of Ageing 2015; 6: 123-32.

34 ONS. Adult Health in Great Britain, 2013. 2015.

https://www.ons.gov.uk/peoplepopulationandcommunity/healthandsocialcare/healthandlife expectancies/compendium/opinionsandlifestylesurvey/2015-0319/adulthealthingreatbritain2013 (accessed Nov 26, 2020).

35 Garrow V. Presenteeism: A review of current thinking. Institute for Employment Studies. 2016. https://www.employment-studies.co.uk/system/files/resources/files/507_0.pdf (accessed Nov 26, 2020).

36 Aiyar MS, Ebeke C, Shao X. The impact of workforce aging on European productivity. IMF. 2016. https://www.imf.org/external/pubs/ft/wp/2016/wp16238.pdf (accessed Nov 26, 2020).

37 Valtorta NK, Kanaan M, Gilbody S, Ronzi S, Hanratty B. Loneliness and social isolation as risk factors for coronary heart disease and stroke: systematic review and meta-analysis of longitudinal observational studies. Heart 2016; 102: 1009-16.

38 Courtin E, Knapp M. Social isolation, loneliness and health in old age: a scoping review. Health Soc Care Community 2017; 25: 799-812.

39Culyer AJ. The nature of the commodity'health care'and its efficient allocation. Oxford Economic Papers 1971; 23: 189-211.

40 Ryan M, Shackley P. Assessing the benefits of health care: how far should we go? Quality in Health Care 1995; 4: 207-13.

41 Leon DA, Jdanov DA, Shkolnikov VM. Trends in life expectancy and age-specific mortality in England and Wales, 1970-2016, in comparison with a set of 22 high-income countries: an analysis of vital statistics data. The Lancet Public Health 2019; 4: e575-82.

42 Mckee M, Hussey R, Dunnell K, et al. The LSE-Lancet Commission 'The Future of the NHS': The Changing Health Needs of the UK Population. The Lancet (In Press) 2021. 
43 Whitehead M, Dahlgren G. What can be done about inequalities in health? The Lancet 1991; 338: 1059-63.

44 Marmot M. Fair Society Healthy Lives (The Marmot Review). Institute of Health Equity. 2010. http://www.instituteofhealthequity.org/resources-reports/fair-society-healthy-livesthe-marmot-review (accessed Nov 26, 2020).

45 Rajan S, McKee M. NHS is picking up the pieces as social safety nets fail. $B M J 2019$; 365: 12360 .

46 NHS England. Technical Guide to Allocation Formulae and Pace of Change: For 2019/20 to 2023/24 revenue allocations. 2019. https://www.england.nhs.uk/wpcontent/uploads/2019/08/allocations-2019-20-technical-guide-to-formulae-v1.1.pdf (accessed Nov 26, 2020).

47 van Doorslaer E, Wagstaff A, van der Burg H, et al. The redistributive effect of health care finance in twelve OECD countries. Journal of Health Economics 1999; 18: 291-313.

48 HM Revenues \& Customs. HMRC Tax Receipts and National Insurance Contributions for the UK. 2019. https://www.gov.uk/government/statistics/hmrc-tax-and-nics-receipts-forthe-uk (accessed Nov 26, 2020).

49 Pope T, Miller H. The changing composition of UK tax revenues. Institue for Fiscal Studies. 2016 https://www.ifs.org.uk/uploads/publications/bns/BN_182.pdf (accessed Nov $26,2020)$.

50 Asaria M, Doran T, Cookson R. The costs of inequality: whole-population modelling study of lifetime inpatient hospital costs in the English National Health Service by level of neighbourhood deprivation. J Epidemiol Community Health 2016; 70: 990-6.

51 OECD, Eurostat, WHO. A System of Health Accounts 2011. 2017 https://www.oecdilibrary.org/content/publication/9789264270985-en. (accessed Nov 26, 2020).

52 OECD Statistics. https://stats.oecd.org/\# (accessed Nov 26, 2020).

53 Anderson M, O'Neill C, Clark JM, et al. LSE-Lancet Commission: 'The Future of the NHS': Securing a sustainable, fit for purpose health and care workforce. The Lancet (In Press). 2021

54 OBR. Fiscal sustainability analytical papers: Fiscal sustainability and public spending on health. 2016. http://obr.uk/fsr/fiscal-sustainability-analytical-papers-july-2016/ (accessed Nov 26, 2020).

55 OECD. Public spending on health and long-term care: a new set of projections. 2013 https://www.oecd.org/eco/growth/Health\%20FINAL.pdf (accessed Nov 26, 2020).

56 ONS. Healthcare expenditure, UK Health Accounts: 2018. 2020.

https://www.ons.gov.uk/peoplepopulationandcommunity/healthandsocialcare/healthcaresy stem/bulletins/ukhealthaccounts/2018

https://www.oecd.org/eco/growth/Health\%20FINAL.pdf (accessed Nov 26, 2020). 
57 Jayawardana S, Cylus J, Mossialos E. It's not ageing, stupid: why population ageing won't bankrupt health systems. Eur Heart J Qual Care Clin Outcomes 2019; 5(3):195-201

58 OBR. Fiscal sustainability report: July 2018. 2018. https://cdn.obr.uk/FSR-July-20181.pdf (accessed Nov 26, 2020).

59 ONS. Population estimates time series dataset. 2019.

https://www.ons.gov.uk/peoplepopulationandcommunity/populationandmigration/populati onestimates/datasets/populationestimatestimeseriesdataset (accessed Nov 26, 2020).

60 Keep M. The Barnett formula. House of Commons Library. 2018. https://researchbriefings.parliament.uk/ResearchBriefing/Summary/CBP-7386 (accessed Nov 26, 2020).

61 Stoye G. Recent trends in independent sector provision of NHS-funded elective hospital care in England. Institue of Fiscal Studies. 2019. https://www.ifs.org.uk/publications/14593 (accessed Nov 26, 2020).

62 Kelly E, Stoye G. The impacts of private hospital entry on the public market for elective care in England. Journal of Health Economics 2020; 73: 102353.

63 Gutacker N, Street A. Multidimensional performance assessment of public sector organisations using dominance criteria. Health Economics 2018; 27: e13-27.

64 Anderson M, Cherla A, Wharton G, Mossialos E. Improving transparency and performance of private hospitals. BMJ 2020; 368. DOI:10.1136/bmj.m577.

65 BMA. Independent Sector Provision in the NHS revisited. 2018 https://www.bma.org.uk/media/1984/bma-privatisation-of-the-nhs-in-england-jan2019.pdf (accessed Nov 28, 2020).

66 Richards M, Anderson M, Carter P, Ebert BL, Mossialos E. The impact of the COVID-19 pandemic on cancer care. Nature Cancer 2020; 1-3.

67 Dilnot A. Fairer Care Funding: The Report of the Commission on Funding of Care and Support. 2011.

https://webarchive.nationalarchives.gov.uk/20130221121529/https://www.wp.dh.gov.uk/c arecommission/files/2011/07/Fairer-Care-Funding-Report.pdf (accessed Nov 26, 2020).

68 Phillips D, Simpson P. Changes in councils' adult social care and overall service spending in England, 2009-10 to 2017-18. Institute for Fiscal Studies. 2018.

https://www.ifs.org.uk/publications/13066 (accessed Nov 26, 2020).

69 ONS. Deaths involving COVID-19 in the care sector, England and Wales. 2020.

https://www.ons.gov.uk/peoplepopulationandcommunity/birthsdeathsandmarriages/deaths/ articles/deathsinvolvingcovid19inthecaresectorenglandandwales/deathsoccurringupto12jun e2020andregisteredupto20june2020provisional (accessed Nov 26, 2020).

70 National Records of Scotland Web. Deaths involving coronavirus (COVID-19) in Scotland. /statistics-and-data/statistics/statistics-by-theme/vital-events/generalpublications/weekly-and-monthly-data-on-births-and-deaths/deaths-involving-coronaviruscovid-19-in-scotland (accessed Nov 26, 2020). 
71 Northern Ireland Statistics and Research Agency. Weekly Deaths. https://www.nisra.gov.uk/publications/weekly-deaths (accessed Nov 26, 2020).

72 van Doorslaer E, Masseria C, Koolman X. Inequalities in access to medical care by income in developed countries. CMAJ 2006; 174: 177-83.

73 Wagstaff A, Flores G, Hsu J, et al. Progress on catastrophic health spending in 133 countries: a retrospective observational study. The Lancet Global Health 2018; 6: e16979 .

74 ONS. Detailed household expenditure by gross income quintile group, UK, financial year ending 2015 to financial year ending 2017. 2018.

https://www.ons.gov.uk/peoplepopulationandcommunity/personalandhouseholdfinances/e xpenditure/adhocs/008735detailedhouseholdexpenditurebygrossincomequintilegroupukfin ancialyearending2015tofinancialyearending2017 _ (accessed Nov 26, 2020).

75 King D, Mossialos E. The Determinants of Private Medical Insurance Prevalence in England, 1997-2000. Health Services Research 2005; 40: 195-212.

76 Foubister T, Thomson S, Mossialos E, McGuire A. Private medical insurance in the United Kingdom. European Observatory on Health Systems and Policies. Cromwell Press. 2006.

77 Thomson S, Cylus J, Evetovits T. Can people afford to pay for health care? New evidence on financial protection in Europe. World Health Organisation. 2019. https://apps.who.int/iris/bitstream/handle/10665/311654/9789289054058-eng.pdf (accessed Nov 26, 2020).

78 ONS. Expenditure on Healthcare in the UK: 2013. 2015

https://www.ons.gov.uk/peoplepopulationandcommunity/healthandsocialcare/healthcaresy stem/articles/expenditureonhealthcareintheuk/2015-03-26 (accessed Nov 26, 2020).

79 Parkin E, Bate A, Loft P. NHS charges. House of Commons Library. 2018. https://researchbriefings.parliament.uk/ResearchBriefing/Summary/CBP-7227 (accessed Nov 26, 2020).

80 O'Dowd NC, Kumpunen S, Holder H. Can people afford to pay for health care? New Evidence on financial protection in the United Kingdom. World Health Organisation. 2018. http://www.euro.who.int/_data/assets/pdf_file/0010/373690/uk-fp-reporteng.pdf?ua $=1$. (accessed Nov 26, 2020).

81 Blackburn, P. Health Cover - UK Market Report. LaingBuisson. 2017.

82 OBR. Fiscal sustainability report, Drivers of rising health spending.

2015 http://obr.uk/box/drivers-of-rising-health-spending/ (accessed Nov 26, 2020).

83 OBR. Economic and fiscal outlook: March 2019. https://cdn.obr.uk/March2019_EFO_Web-Accessible.pdf (accessed Nov 26, 2020).

84 Johansson Å, Guillemette Y, Murtin F, et al. Long-Term Growth Scenarios. OECD. 2013. https://www.oecd-ilibrary.org/economics/long-term-growth-scenarios_5k4ddxpr2fmr-en (accessed Nov 26, 2020). 
85 Darzi A. The Lord Darzi Review of Health and Care: Interim report. Institute for Public Policy Research. 2018. https://www.ippr.org/research/publications/darzi-review-interimreport (accessed Nov 26, 2020).

86 Baumol WJ, Bowen WG. Performing Arts: The Economic Dilemma - A Study of Problems Common to Theater, Opera, Music and Dance. Cambridge, Massachusetts, United States. MIT Press, 1968.

87 Colombier C. Drivers of Health Care Expenditure: Does Baumol's Cost Disease Loom Large? FiFo Discussion Paper No. 12-5. 2012 https://papers.ssrn.com/abstract=2341054 (accessed Nov 26, 2020).

88 Baumol WJ. Social Wants and Dismal Science: The Curious Case of the Climbing Costs of Health and Teaching. Proceedings of the American Philosophical Society 1993; 137: 612-37.

89 Sorenson C, Drummond M, Bhuiyan Khan B. Medical technology as a key driver of rising health expenditure: disentangling the relationship. Clinicoecon Outcomes Res 2013; 5: 223-34.

90 Sheikh A, Anderson M, Albala S, et al. LSE-Lancet Commission 'The Future of the NHS': Leveraging Health Information Technology and Catalysing Digital Innovation to Create a National Learning Health and Care System. The Lancet Digital Health (In Press) 2021.

91 Wittenberg R, Hu B, Hancock R. Projections of demand and expenditure on adult social care 2015 to 2040. Personal Social Services Research Unit. 2018. http://eprints.lse.ac.uk/88376/ (accessed Nov 26, 2020).

92 Nuffiled Trust. The Health Foundation. The King's Fund. The Autumn Budget: Joint statement on health and social care. $2017 \mathrm{https} / / / \mathrm{www}$.health.org.uk/publications/theautumn-budget (accessed Nov 26, 2020).

93 UK Government. Care Act 2014: cap on care costs and appeals (Consultation). https://www.gov.uk/government/consultations/care-act-2014-cap-on-care-costs-andappeals (accessed Nov 26, 2020).

94 Jarrett T. Social care: the Conservative Party's 2017 General Election pledges on how individuals pay for care. House of Commons Library. 2018. https://researchbriefings.parliament.uk/ResearchBriefing/Summary/CBP-8001 (accessed Nov 26, 2020).

95 The Conservative and Unionist Party Manifesto 2019. https://vote.conservatives.com/ourplan (accessed Nov 26, 2020).

96 Watt T, Varrow M, Charlesworth A, et al. Social care funding options. The Health Foundation. 2018. https://www.health.org.uk/publications/social-care-funding-options (accessed Nov 26, 2020).

97 Castelli A, Chalkley MJ, Gaughan JM et al. Productivity of the English National Health Service : 2016/17 update. Centre for Health Economics, University of York, 2019. http://eprints.whiterose.ac.uk/145037/ (accessed Nov 26, 2020). 
98 ONS. Public service productivity: total, UK, 2017. 2020.

https://www.ons.gov.uk/economy/economicoutputandproductivity/publicservicesproductiv ity/articles/publicservicesproductivityestimatestotalpublicservices/totaluk2017 (accessed Nov 26, 2020).

99Dixon J, Street A, Allwood D. Productivity in the NHS: why it matters and what to do next. $B M J 2018 ; 363: \mathrm{k} 4301$.

100 Bloom N, Sadun R, Van Reenen J. Americans Do IT Better: US Multinationals and the Productivity Miracle. The American Economic Review 2012; 102: 167-201.

101 Kumar S, Russell RR. Technological Change, Technological Catch-up, and Capital Deepening: Relative Contributions to Growth and Convergence. American Economic Review 2002; 92: 527-48.

102 Kraindley J, Firth Z, Charlesworth A. False economy: An analysis of NHS funding pressures. The Health Foundation. 2018

https://www.health.org.uk/sites/default/files/False-economy-NHS-funding-pressures-May2018.pdf (accessed Nov 26, 2020).

103 Kraindler J, Gershlick B, Charlesworth A. Failing to capitalise: capital spending in the NHS. The Health Foundation. 2019.

https://www.health.org.uk/publications/reports/failing-to-capitalise (accessed Nov 26, 2020). 